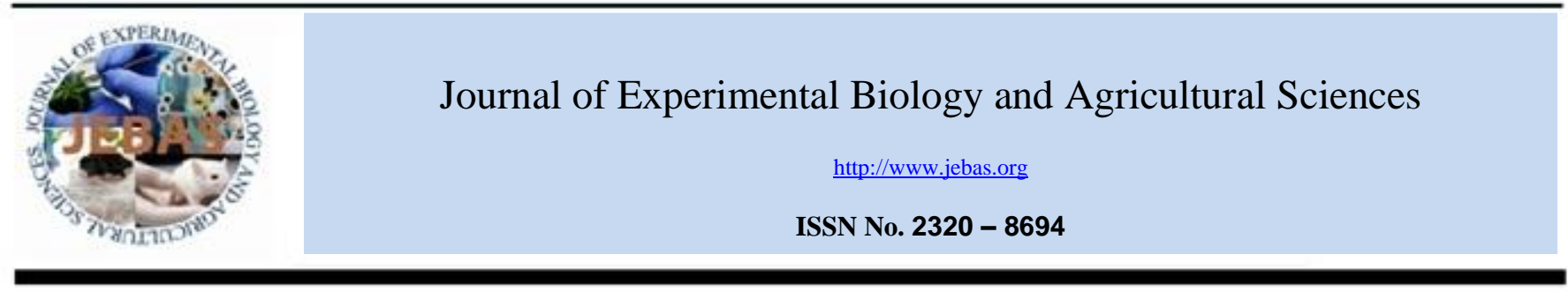

\title{
DIVA TECHNOLOGY: INDISPENSABLE TOOL FOR THE CONTROL OF JOHNE'S DISEASE
}

\author{
Sujata Jayaraman ${ }^{1, \#}$, Mukta Jain ${ }^{1, \#}$, Kuldeep Dhama ${ }^{2}$, S V Singh ${ }^{3}$, Manali Datta ${ }^{4}$, Neelam Jain ${ }^{4}$, K K \\ Chaubey $^{3}$, S Gupta ${ }^{3}$, G K Aseri ${ }^{1}$, Neeraj Khare ${ }^{1}$, Parul Yadav ${ }^{5}$, A K Bhatia ${ }^{6}$ and J S Sohal ${ }^{1 . *}$ \\ ${ }^{1}$ Amity Institute of Microbial Technology, Amity University Rajasthan, Kant Kalwar, NH-11C Delhi-Jaipur Highway, Jaipur- 303 002, India \\ ${ }^{2}$ Division of Pathology, Indian Veterinary Research Institute, Izatnagar, Bareilly- \\ 243122, Uttar Pradesh, India \\ ${ }^{3}$ Animal Health Division, Central Institute for Research on Goats, Makhdoom, PO - Farah, Mathura- 281122, Uttar Pradesh, India \\ ${ }^{4}$ Amity Institute of Biotechnology, Amity University Rajasthan, Kant Kalwar, NH-11C Delhi-Jaipur Highway, Jaipur- 303 002, India \\ ${ }^{5}$ Amity University Science \& Instrumentation Centre, Amity University Rajasthan, Kant Kalwar, NH-11C Delhi-Jaipur Highway, Jaipur- 303 002, India \\ ${ }^{6}$ Department of Microbiology and Immunology, GLA University, Chaumuhan, Mathura, Uttar Pradesh, India
}

Received - November 23, 2015; Revision - December 14, 2015; Accepted - January 27, 2016

Available Online - February 15, 2016

DOI: http://dx.doi.org/10.18006/2015.4(1).16.25

\begin{abstract}
KEYWORDS
Paratuberculosis

Tuberculosis

Johne's disease

Secreted antigens

DIVA

Vaccine

Vaccination

ABSTRACT

Ruminant Paratuberculosis (Johne's disease) is categorized as List B disease by OIE. Paratuberculosis is a disease of socio-economic and public health importance and has significant effect on in the international trade of animals and animal products. Control of paratuberculosis is priority in many countries and different countries have designed their own control programs tailored to their farming practices and geographical conditions. However, the major component shared by these control programs is "Test and Cull" policy. Due to inability of detecting paratuberculosis in early stages this policy has globally failed to control the disease and hence there is global urgency in developing control measures. Vaccination has shown promise in controlling this disease. However, vaccination in present form cannot be used due to lack of DIVA (Differentiation of Infected from Vaccinated Animals) technology, because present vaccines interfere with diagnosis of naturally infected paratuberculosis animals and animals infected with tuberculosis. Therefore markers are needed to be identified for developing DIVA. This paper summarizes the findings of vaccination trials conducted in different countries and highlights the importance of vaccination in controlling paratuberculosis and also discusses strategies for developing DIVA for paratuberculosis vaccines.
\end{abstract}

* Corresponding author (\# Authors equally contributed to this work)

E-mail: sohal_lucky@ymail.com (J S Sohal)

Peer review under responsibility of Journal of Experimental Biology and Agricultural Sciences.

Production and Hosting by Horizon Publisher (http://publisher.jebas.org/index.html).

All rights reserved.
All the article published by Journal of Experimental Biology and Agricultural Sciences is licensed under a Creative Commons Attribution-NonCommercial 4.0 International License Based on a work at www.jebas.org.

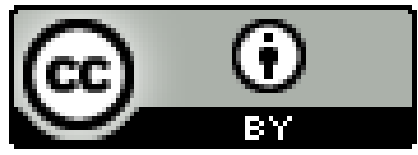




\section{Introduction}

Johne's disease (JD) or Paratuberculosis has emerged as widespread, highly prevalent and economically devastating infectious disease of domestic livestock around the world (Singh et al., 2014). JD is characterized by persistent diarrhea with progressive loss of weight. Chronic diarrhoea results in protein losing enteropathy. Disease is caused by an extremely fastidious microbe known as Mycobacterium avium subspecies paratuberculosis (MAP). It is highly resistant to environmental stress like temperature, drying and is able to persist for years in farm soil (Singh et al., 2013). In India disease has been widely reported from all the domestic ruminant species (Singh et al., 2014). In India MAP has also been reported from wild ruminants such as blue bulls, hog deer, bison (Singh et al., 2010a; Singh et al., 2011a) as well as other animals like rabbit and primates (Singh et al., 2011b; Singh et al., 2012).

Paratuberculosis is a spectral disease where it takes years for clinical signs to appear in animals. In very early stages (silent stage) typically there are no signs of disease and none of the available tests can detect infected animals at this stage, this stage progresses to sub-clinical disease, where shedding of MAP in feces can be occasionally seen without any signs of the disease (Tiwari et al., 2006). This stage often then progresses to clinical infection. At this stage animal have intermittent diarrhea and progressive weight loss without reduction of appetite. Sporadic signs at this stage generally give way to more severe infection. These animals will give positive results with fecal culture tests, because of host shedding massive numbers of organism. Animals in this stage are also positive on serological assays. Clinical signs continue for months, which may usually results in death.

Paratuberculosis is increasingly being recognized as significant problem affecting animal health, farming and the food industry due to the high prevalence of the disease across the world. Paratuberculosis can cause significant economic loss in affected herds, as a result of reduced milk yield, poor milk quality, poor feed conversion, increased susceptibility to disease in general, reduced reproductive efficiency, premature culling and reduced slaughter values. It is estimated that $68.0 \%$ of US dairy herds are infected with JD, costing between $\$ 200$ million to $\$ 1.5$ billion per year to dairy industry (Sohal et al., 2015). A study from India by Vinodhkumar et al. (2013) estimated loss of Rs 1,840 (US\$ 38.33) per infected sheep/year. Another study from India in a Holstein Frisian (H/F) dairy farm estimated loss of Rs $1,63,800.0$ (US\$ 2465) in 180 days due to JD (Rawat et al., 2014). Besides costly to animal husbandry, MAP is gaining interest as a zoonotic and food-borne pathogen. Evidences suggest the involvement of MAP in human diseases like Crohn's disease and type I diabetes (Sohal et al., 2015). MAP is not killed by pasteurization and milk has been considered as main source of infection transmission to humans. MAP has frequently been isolated from pasteurized milk and milk products (Shankar et al., 2010). Rising concern of the MAP zoonosis has generated lot of awareness among veterinarians and medicos seeking to control this disease in animals. Therefore paratuberculosis needs immediate attention for control in animals. This paper discusses the role of vaccination and DIVA (Differentiation of Vaccinated \& Infected Animals) technology in efforts to control Johne's disease.

\section{Vaccination as tool of Paratuberculosis Control}

Due to predominant subclinical nature of disease and prolonged course of infection, early diagnosis is not possible therefore control of paratuberculosis is problematic task. The most widely practiced control strategy for paratuberculosis is test and cull policy. However, due to lack of tools to detect disease in early stages; test and cull policy is not sufficient in preventing spread of MAP (Bastida \& Juste, 2011). Despite test and cull policies in place disease burden has continued to increase (Singh et al., 2014). Positivity (number of positive animals vs number of tested animals) of ruminant species in India for paratuberculosis (cattle, goat, sheep and buffalo) increased from $11.6 \%$ to $23.3 \%$ over the period of 28 years (1985-2013) (Singh et al., 2014). Therefore alternate strategies are required if control of paratuberculosis is to be achieved.

Vaccination programs in past have been successfully deployed. As a result, there is increased interest in use of vaccination against paratuberculosis. Vaccination is a cost-effective strategy for paratuberculosis containment (Singh et al., 2007; Juste \& Perez, 2011; Bush et al., 2008; Dhand et al., 2013). Vaccination reduces morbidity \& mortality due to JD, reduces shedding of MAP in feces, improves clinical signs (reduces diarrhea \& increases body weight), cures intestinal lesions and enhances flock immunity to JD (Singh et al., 2007; Singh et al., 2010b; Singh et al., 2013). Studies have confirmed that vaccination not only reduces the prevalence of JD but also has economic benefits to farmers (Groenendaal et al., 2015). Vaccination also provides revival against MAP infection i.e. therapeutic effects observed in already infected animals (Singh et al., 2010b).

Benefits of vaccination have been summarized in Table 1. Therefore vaccination is being considered an economically attractive tool for controlling Johne's disease (Sohal et al., 2015). Examples are there from countries like Iceland and Australia where compulsory vaccination programs brought about sufficient reductions in prevalence of paratuberculosis (Sohal et al., 2015). Another indirect benefit of paratuberculosis vaccination is that there is some degree of cross protection for tuberculosis (de Val et al., 2012). Both killed and live attenuated vaccines have the same efficiency in controlling paratuberculosis (Singh et al., 2007) however, killed vaccines have longer shelf life and are safer. 
Table 1 Beneficial effects of vaccination against MAP

\begin{tabular}{|c|c|c|c|c|c|}
\hline $\begin{array}{l}\text { S. } \\
\text { No. }\end{array}$ & Name/ kind of vaccine & Country & Species & Major Observation & Reference \\
\hline 1. & $\begin{array}{l}\text { Laboratory Scale } \\
\text { (Live) }\end{array}$ & USA & Cattle & \multirow[t]{10}{*}{$\begin{array}{l}\text { Vaccination reduces fecal } \\
\text { shedding of MAP }\end{array}$} & Larsen et al., 1974 \\
\hline 2. & Fromm (Killed) & USA & Cattle & & Hurley \& Ewing 1983 \\
\hline 3. & $\begin{array}{l}\text { Laboratory Scale } \\
\text { (Live) }\end{array}$ & Denmark & Cattle & & Jorgensen, 1983 \\
\hline 4. & $\begin{array}{l}\text { Laboratory Scale } \\
\text { (Live) }\end{array}$ & France & Cattle & & Argente, 1992 \\
\hline 5. & Phylaxia (Killed) & Hungary & Cattle & & Kormendy, 1994 \\
\hline 6. & Neoparasec (Live) & Germany & Cattle & & Klawonn et al., 2002 \\
\hline 7. & Lio-Johne (Live) & Spain & Sheep & & Aduriz, 1993 \\
\hline 8. & $\begin{array}{l}\text { Laboratory Scale } \\
\text { (Live) }\end{array}$ & Greece & Sheep & & Dimareli-Malli et al., 2013 \\
\hline 9. & Live Vaccine & New Zealand & Sheep & & Gwodz et al., 2000 \\
\hline 10. & Killed vaccine & - & Goat & & $\begin{array}{l}\text { Kalis et al., } \\
2001\end{array}$ \\
\hline 11. & Weybridge (Live) & UK & Cattle & \multirow{5}{*}{$\begin{array}{l}\text { Vaccination improves } \\
\text { production }\end{array}$} & Wilesmith, 1982 \\
\hline 12. & Lelystad (Killed) & Netherlands & Cattle & & Kalis et al., 1992 \\
\hline 13. & Lio-Johne (Live) & Spain & Sheep & & Aduriz, 1993 \\
\hline 14. & Gudair (Killed) & Australia & Sheep & & Windsor et al., 2003 \\
\hline 15. & Neoparasec (Live) & New Zealand & Sheep & & Gwozdz et al., 2000 \\
\hline 16. & $\begin{array}{l}\text { Laboratory Scale } \\
\text { (Killed) }\end{array}$ & Netherlands & Cattle & \multirow[t]{7}{*}{$\begin{array}{l}\text { Histological improvement } \\
\text { after vaccination }\end{array}$} & van Schaik et al., 1996 \\
\hline 17. & Silirum (Killed) & Spain & Cattle & & Garcia-Pariente et al., 2005 \\
\hline 18. & $\begin{array}{l}\text { Laboratory Scale } \\
\text { (Killed) }\end{array}$ & Iceland & Sheep & & Sigurdsson, 1960 \\
\hline 19. & Lio-Johne (Live) & Spain & Sheep & & Aduriz, 1993 \\
\hline 20. & Mycopar (Killed) & USA & Sheep & & Thonney \& Smith, 2005 \\
\hline 21. & $\begin{array}{l}\text { Laboratory Scale } \\
\text { (Live) }\end{array}$ & Norway & Goat & & Saxegaard \& Fodstad, 1985 \\
\hline 22. & $\begin{array}{l}\text { Laboratory Scale } \\
\text { (Killed) }\end{array}$ & USA & Goat & & Kathaperumal et al., 2009 \\
\hline 23. & $\begin{array}{l}\text { Laboratory Scale } \\
\text { (Killed) }\end{array}$ & India & Goat & $\begin{array}{l}\text { Histological improvements, } \\
\text { reduction fecal shedding, } \\
\text { improves production and } \\
\text { therapeutic effects }\end{array}$ & $\begin{array}{l}\text { Singh et al., 2007; Singh et } \\
\text { al., } 2010 \text { b }\end{array}$ \\
\hline 24. & Gudair (killed) & $\begin{array}{l}\text { Australia, New } \\
\text { Zealand and } \\
\text { Spain }\end{array}$ & $\begin{array}{l}\text { Goat and } \\
\text { Sheep }\end{array}$ & $\begin{array}{l}\text { Histological improvement, } \\
\text { reduction fecal shedding, } \\
\text { improves production }\end{array}$ & $\begin{array}{l}\text { Griffin et al., 2009; } \\
\text { Reddacliff et al., 2006; } \\
\text { Eppleston et al., 2004; Corpa } \\
\text { et al., } 2000\end{array}$ \\
\hline 25. & Killed Vaccine & Iceland & Sheep & $\begin{array}{l}\text { Reduction in mortality, } \\
\text { improves clinical signs and } \\
\text { reduction in fecal shedding of } \\
\text { MAP }\end{array}$ & $\begin{array}{l}\text { Sigurdsson \& Gunnarson, } \\
1983\end{array}$ \\
\hline 26. & Live Vaccine & Cyprus & Sheep & $\begin{array}{l}\text { Reduction in mortality, } \\
\text { improves clinical signs and } \\
\text { reduction in fecal shedding of } \\
\text { MAP }\end{array}$ & Crowther et al., 1976 \\
\hline
\end{tabular}




\section{Issues of Paratuberculosis Vaccination}

Vaccination efforts against paratuberculosis have succeeded numerous times (Table 1); however, there are several issues in implementing vaccination programs. First, vaccination against paratuberculosis may interfere with routine diagnosis of paratuberculosis. ELISA is the most widely used test for diagnosing paratuberculosis because of low cost, rapid turnaround time and high sensitivity. Other tests are costly, time consuming, have poor sensitivity and requires sophisticated facilities so are of limited utility when incorporated into paratuberculosis control programs. However, presently available ELISAs cannot discriminate vaccinated individuals from naturally infected individuals. ELISA results can be a problematic in certifying herds for disease (paratuberculosis) free status where a compulsory vaccination has either lowered the prevalence or eradicated the disease from herd due to the fact that these tests can't discriminate between pathogen and vaccine-induced immunological responses. Since positive ELISA diagnostic test results for MAP are often sufficient in triggering herd cull responses, false positive results can be economically disastrous for cattle farms. Secondly, vaccination against paratuberculosis will interfere with diagnosis with tuberculosis and there are evidences on this (Juste \& Perez, 2011).

MAP and $M$. bovis share antigenic structures; therefore immune responses generated by vaccination against these two can interfere with diagnosis of paratuberculosis as well as tuberculosis. Hence, implementing vaccination against MAP will not only affect the diagnosis of paratuberculosis but will also affect the tuberculosis control programs. Considering these issues most of the countries are hesitant to vaccinate against MAP. This problem is not just restricted to paratuberculosis, there are number of animal diseases where vaccines are available but cannot be used. One example is FMD; vaccines are available and are quite effective in controlling clinical disease but are not used in disease free countries, as it interferes with diagnostic test results. Positive immunological test results could ruin the disease free status even of vaccinated healthy livestock populations, which, in turn, can lead to serious economic losses in a region's agronomy (Meeusen et al., 2007).

\section{DIVA Technology}

The primary goal of vaccination is to help in elimination of disease. However, vaccinations elicit immune responses similar to those found infected animals, thereby rendering traditional diagnostic screening protocols useless as a means of determining true herd disease status. Therefore it is essential to differentiate immune responses due to vaccination compared to natural infection. The term Differentiation of Infected from Vaccinated Animals (DIVA) was coined in 1999 by Jan T. van Oirschot (van Oirschot, 1999). It is now generally used in place of older term 'marker vaccines'. The DIVA principle has now also been extended to include killed whole organism vaccines (Pasick, 2004). The general DIVA principle is that antibody response produced by vaccination can be differentiated from the antibody response elicited by natural infection.

DIVA tests work by detection of immune response against specific antigens which are present in the infectious agent but in the absence of vaccine. Successful DIVA technologies has been developed for animal vaccines like bovine rhinotracheitis (IBR), pseudorabies, classical swine fever (CSF) etc (Meeusen et al., 2007). Strategies for developing DIVA based vaccines for other diseases like bovine tuberculosis (Vordermeier et al., 2001), avian influenza (Rahn et al., 2015), PPR (Liu et al., 2014) and bluetongue virus (Calvo-Pinilla et al., 2014) are also under development. Though there has been great demand to develop DIVA strategies for paratuberculosis, so far no progress has been made and to our knowledge there is no laboratory working on it. Till date, vaccination is the only practical method for controlling paratuberculosis.

Since popular commercially available paratuberculosis vaccines are whole cell killed preparations, simple strategies can be designed to develop DIVA technology to differentiate infected and vaccinated animals. Killed whole cell vaccines will generate immune response only against cellular antigens i.e. vaccinated animals will only have antibodies against cellular antigens. However, in naturally infected animals will have antibodies against both cellular and secreted (culture filtrate antigens) antigens. Immune response against secreted antigens can be selectively used to differentiate vaccinated and naturally infected animals (Fig. 1). Therefore secreted antigens of MAP can serve as markers of differentiation between vaccinated and naturally infected animals and can be used to develop DIVA. There have been reports that secreted antigens are released early during the infection process and elicit antibody responses (Ahmad, 2010), hence these can be used as markers for early sero-diagnosis of paratuberculosis in early or subclinical stages (Facciuolo et al., 2013). Presently available commercial ELISAs contain a crude antigen mixture termed PPA, which is prepared by thorough physical disruption of mycobacterial bacilli followed by removal of cell debris.

The low sensitivity of available conventional ELISA tests can be attributed to the lack of secreted antigens. Hence, a simple ELISA based test can be developed using secreted antigens to diagnose paratuberculosis as well as the same secreted antigens based ELISA can be used to differentiate vaccinated and infected animals if used in conjunction with conventional ELISA protocols (Table 2). If MAP specific secreted antigens are incorporated in this system then same ELISA regimen can be used for diagnosis, DIVA marker detection and for differentiating paratuberculosis \& tuberculosis infection. Table 3 summarizes the MAP secreted proteins that can be used to develop DIVA for killed whole cell vaccines and for differentiating paratuberculosis and tuberculosis. 


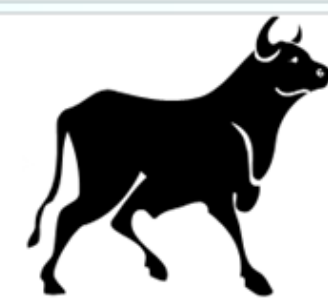

Infected Animal

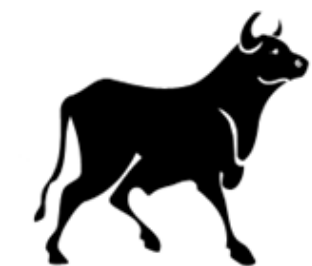

Vaccinated Animal

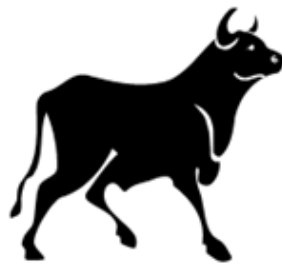

Healthy Animal

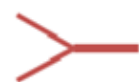

Antibodies to cytoplasmic Antigens

L
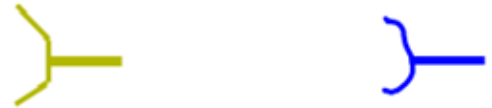

Antibodies to cell wall antigens .

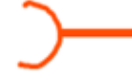

Antibodies to secretory antigens

\section{Antibodies to Cellular Antigens}

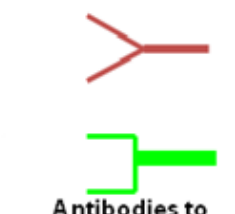

ytoplasmic Antigens

L

\section{Antibodies to Cellular Antigens}

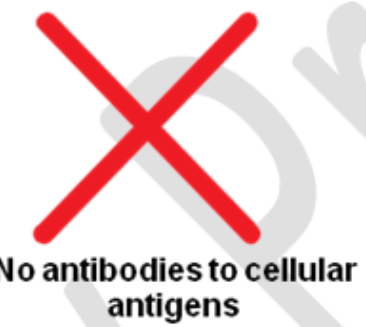

\section{No antibodies to secreted antigens}

Figure 1 Scheme of the immune response that can be used to differentiate vaccinated and naturally infected animals.

Table 2 Scheme of the differentiation of healthy, infected and vaccinated animals

\begin{tabular}{|l|c|c|}
\hline Kind of Animal & $\begin{array}{c}\text { Status of Animal in } \\
\text { Conventional ELSIA }\end{array}$ & $\begin{array}{c}\text { Status of Animal in Secreted } \\
\text { Antigens based ELISA }\end{array}$ \\
\hline Healthy & Negative & Negative \\
\hline Naturally Infected & Positive & Positive \\
\hline Vaccinated & Positive & Negative \\
\hline
\end{tabular}

\section{Concluding Remarks}

Paratuberculosis is a devastating disease, negatively affecting the livestock agronomy throughout the world, its presence triggers trade restrictions and raises serious public health concerns. Therefore control of paratuberculosis is of the utmost urgency. Most extensively accepted "Test and Cull" policy is very costly to farmers and governments; moreover it is not particularly effective in stemming the physical spread of MAP from one region to the next. Through the scientific, technical and farming experiences it is becoming clear that vaccination is the only practical solution for controlling this disease. However, in the absence of DIVA technology, vaccination programs cannot be implemented at national scale, as vaccinations often elicit immune responses indistinguishable from those generated by pathogens (using standard test regimens). 
Table 2 List of secreted MAP proteins that can be used to develop DIVA (in killed whole cell vaccine system) and for differentiating paratuberculosis and tuberculosis.

\begin{tabular}{|c|c|c|c|}
\hline S. No. & Secreted Protein & Function & Remark \\
\hline 1. & MAP 2609 & - & Tested for antigenicity by Willemsem et al. (2006) \\
\hline 2. & MAP 2942c & - & Tested for antigenicity by Willemsem et al. (2006) \\
\hline 3. & MAP 0210c & - & $\begin{array}{l}\text { Tested for antigenicity by Willemsem et al. (2006); Mon } \\
\text { et al. (2012) }\end{array}$ \\
\hline 4. & MAP 0209 & - & Tested for antigenicity by Mon et al. (2012) \\
\hline 5. & MAP 0187c & - & Tested for antigenicity by Mon et al. (2012) \\
\hline 6. & MAP 1272 & Putative invasin, NlpC/P60 superfamily & Tested for antigenicity by Mon et al. (2012) \\
\hline 7. & MAP 1569/ ModD & - & Tested for antigenicity by Souza et al. (2011) \\
\hline 8. & MAP 0471 & - & Tested for antigenicity by Facciuolo et al. (2013) \\
\hline 9. & MAP $1981 \mathrm{c}$ & - & Tested for antigenicity by Facciuolo et al. (2013) \\
\hline 10. & MAP 0196c & - & $\begin{array}{l}\text { Tested for antigenicity by Facciuolo et al. (2013); Mon et } \\
\text { al. (2012) }\end{array}$ \\
\hline 11. & MAP $1693 c$ & Peptidyl-prolyl cis-trans isomerase & $\begin{array}{l}\text { Tested for antigenicity by Mon et al. (2012); Roupie et } \\
\text { al. (2012) }\end{array}$ \\
\hline 12. & MAP 0853 & - & Tested for antigenicity by Bannantine et al. (2008) \\
\hline 13. & MAP $4308 c$ & - & Tested for immunogenicity by Roupie et al. (2008) \\
\hline 14. & CobT & Phosphoribosyl transferase & Tested for immunogenicity by Byun et al. (2012) \\
\hline 15. & MAP $2168 \mathrm{c}$ & - & Tested for antigenicity by Cho et al. (2007) \\
\hline 16. & MAP $1022 c$ & - & Cho et al. (2006) \\
\hline 17. & Antigen $85 \mathrm{C}$ & Mycolyl transferase & Tested for antigenicity by Shin et al. (2005) \\
\hline 18. & PepA (N-terminal) & Serine proteinase & Tested for antigenicity by Cho et al. (2007) \\
\hline 19. & PepA (C-terminal & Serine proteinase & Tested for antigenicity by Cho et al. (2007) \\
\hline 20. & MAP $3273 c$ & - & Gurung et al. (2014) \\
\hline 21. & AhpC & Alkyl hydroperoxide reductase $\mathrm{C}$ & Tested for antigenicity by Olsen et al. (2001) \\
\hline 22. & AhpD & Alkyl hydroperoxide reductase D & Tested for antigenicity by Olsen et al. (2001) \\
\hline 23. & MAP 3680c & - & Tested for immunogenicity by Carlos et al. (2015) \\
\hline 24. & $\begin{array}{l}\text { Superoxide dismutase } \\
\text { (Sod) }\end{array}$ & - & Tested for antigenicity by Shin et al. (2005) \\
\hline 25. & MAP 0586c & Possible transglycosylase SLT domain & Tested for immunogenicity by Roupie et al. (2008) \\
\hline 26. & MAP $2677 \mathrm{c}$ & Glyoxylase & Tested for antigenicity by Roupie et al. (2012) \\
\hline 27. & MAP 3199 & - & Tested for antigenicity by Leroy et al. (2007) \\
\hline 28. & MAP $1272 c$ & Putative invasin, NlpC/P60 superfamily & Tested for antigenicity by Mon et al. (2012) \\
\hline 29. & MAP 2942c & - & Tested for antigenicity by Gumber et al. (2009) \\
\hline 30. & GreA & Transcription elongation factor GreA & Tested for antigenicity by Mon et al. (2012) \\
\hline 31. & MAP 0593c & - & Tested for antigenicity by Gumber et al. (2009) \\
\hline 32. & MAP 2411 & - & Tested for antigenicity by Kawaji et al. (2012) \\
\hline 33. & MAP2168c & - & Tested for antigenicity by Cho et al. (2007) \\
\hline 34. & Ppa & Inorganic pyrophosphatase & Tested for antigenicity by Gumber et al. (2009) \\
\hline 35. & ClpP & $\begin{array}{l}\text { ATP-dependent Clp protease proteolytic } \\
\text { subunit }\end{array}$ & Tested for antigenicity by Gumber et al. (2009) \\
\hline 36. & $\mathrm{Ag} 85 \mathrm{~A}$ & - & Tested for antigenicity by Rosseels et al. (2006) \\
\hline 37. & $\mathrm{Ag} 85 \mathrm{~B}$ & - & Tested for antigenicity by Rosseels et al. (2006) \\
\hline
\end{tabular}


This, in turn, greatly impairs determination of livestock herd infectious disease status- critical for the entire livestock agronomy. Since killed vaccines have good protective efficacy against paratuberculosis, the strategy proposed in the paper can be used to develop DIVA ELISA using the above comprehensive list of antigens. A careful selection and screening of secretory antigens is performed, we can develop an ELISA based test that can be used as routine diagnostic tool, as a DIVA tool and one that will be able to differentiate paratuberculosis and tuberculosis. We suggest that the development and validation of such a test be carried out on global scale, with many laboratories working in conjunction with one another, so that an effective strategy can be developed for combating the worldwide spread of Johne's disease and animal tuberculosis.

\section{Conflict of interest}

Authors would hereby like to declare that there is no conflict of interests that could possibly arise.

\section{References}

Aduriz JJ (1993) Epidemiologia, diagnostico y control de la paratuberculosis ovina en la Comunidad Autónoma del Pais Vasco. University of Zaragoza, Spain.

Ahmad S (2010) New approaches in the diagnosis and treatment of latent tuberculosis infection. Respiratory Research 11: 169-197. doi: 10.1186/1465-9921-11-169.

Argente G (1992) Efficiency of vaccination and other control measures estimated by fecal culturing in a regional program. In: Chiodini RJ, Kreegel JM (Eds) Proceedings of the 3rd International Colloquium on Paratuberculosis, International Association for Paratuberculosis; Orlando, Florida, USA.Pp.495-503.

Bannantine JP, Bayles O D, Waters WR, Palmer MV, Stabel JR, Paustian ML (2008) Early antibody response against Mycobacterium avium subspecies paratuberculosis antigens in subclinical cattle. Proteome Science 6: 5-16. doi: 10.1186/1477-5956-6-5.

Bastida F, Juste RA (2011) Paratuberculosis control: a review with a focus on vaccination. Journal of Immune Based Therapies Vaccines 9: 8-24. doi: 10.1186/1476-8518-9-8.

Bush RD, Windsor PA, Toribio JA, Webster SR (2008) Financial modeling of the potential cost of ovine Johne's disease and benefit of vaccination in southern New South Wales. Australian Veterinary Journal 86: 398-403. doi: 10.1111/j.1751-0813.2008.00347.x.

Byun EH, Kim WS, Kim JS, Won CJ, Choi HG, Kim HJ, Cho SN, Lee K, Zhang T, Hur GM, Shin SJ (2012) Mycobacterium paratuberculosis CobT activates dendritic cells via engagement of Toll-like receptor 4 resulting in Th1 cell expansion. Journal of Biological Chemistry 287: 38609-38624. doi: 10.1074/jbc.M112.391060.

Calvo-Pinilla E, Castillo-Olivares J, Jabbar T, Ortego J, de la Poza F, Marín-López A (2014) Recombinant vaccines against bluetongue virus. Virus Research 182:78-86. doi: 10.1016/j.virusres.2013.11.013.

Carlos P, Roupie V, Holbert S, Ascencio F, Huygen K, Gomez-Anduro G, Branger M, Reyes-Becerril M, Angulo C (2015) In silico epitope analysis of unique and membrane associated proteins from Mycobacterium avium subsp. paratuberculosis for immunogenicity and vaccine evaluation. Journal of Theoretical Biology 384:1-9. doi: 10.1016/j.jtbi.2015.08.003.

Cho D, Sung N, Collins MT (2006) Identification of proteins of potential diagnostic value for bovine paratuberculosis. Proteomics 6:5785-94.

Cho D, Shin SJ, Talaat AM, Collins MT (2007) Cloning, expression, purification and serodiagnostic evaluation of fourteen Mycobacterium paratuberculosis proteins. Protein Expression and Purification 53: 411-20. doi:10.1016/j.pep.2006.12.022.

Corpa JM, Garrido J, Garcia Marin JF, Perez V (2000) Classification of lesions observed in natural cases of paratuberculosis in goats. Journal of Comparative Pathology 122: 255-265. doi:10.1053/jcpa.1999.0368.

Crowther RW, Polydorou K, Nitti S, Phyrilla A (1976) Johne's disease in sheep in Cyprus. Veterinary Record 98: 463.

de Val BP, Nofrarías M, López-Soria S, Garrido JM, Vordermeier HM, Villarreal-Ramos B, Martín M, Puentes E, Juste RA, Domingo M (2012) Effects of vaccination against paratuberculosis on tuberculosis in goats: diagnostic interferences and cross-protection. BMC Veterinary Research 8:191-201. doi: 10.1186/1746-6148-8-191.

Dhand NK, Johnson WO, Eppleston J, Whittington RJ, Windsor PA (2013) Comparison of pre- and post-vaccination ovine Johne's disease prevalence using a Bayesian approach. Preventive Veterinary Medicine111: 81-91. doi: 10.1016/j.prevetmed.2013.03.003.

Dimareli-Malli Z, Papadopoulos G, Betsas P (2013) Evaluation of a Live Paratuberculosis Vaccine in Endemically Infected Flocks of Sheep and Goats in Greece. Journal of Immune Based Therapies, Vaccines and Antimicrobials 2: 4958. DOI: 10.4236/jibtva.2013.24007.

Eppleston J, Reddacliff L, Windsor P, Whittington R, Jonbes S (2004) Field studies on vaccination for the control of OJD in Australia - and overview. Proceedings of the Australian Sheep Veterinary Society Pp. 56-59. 
Facciuolo A, Kelton DF, Muthariaa LM (2013) Novel Secreted Antigens of Mycobacterium paratuberculosis as Serodiagnostic Biomarkers for Johne's Disease in Cattle. Clinical and Vaccine Immunology 20: 1783-1791. doi: 10.1128/CVI.00380-13.

Garcia-Pariente C, Perez V, Geijo M, Moreno O, Munoz M, Fuertes M, Puentes E, Doce J, Ferreras MC, Garcia Marin JF (2005). In: Proceedings of the 8th International Colloquium on paratuberculosis; Copenhagen, Denmark. In: Manning EJB, Nielsen SS (editors) International Association for Paratuberculosis; The efficacy of a killed vaccine against paratuberculosis (SILIRUM) in cattle. pp52.

Griffin JF, Hughes AD, Liggett S, Farquhar PA, Mackintosh CG, Bakker D (2009) Efficacy of novel lipid-formulated whole bacterial cell vaccines against Mycobacterium avium subsp. paratuberculosis in sheep. Vaccine 27: 911-918. doi: 10.1016/j.vaccine.2008.11.053.

Groenendaal H, Zagmutt FJ, Patton EA, Wells SJ (2015) Costbenefit analysis of vaccination against Mycobacterium avium ssp. paratuberculosis in dairy cattle, given its cross-reactivity with tuberculosis tests. Journal of Dairy Science 98: 6070-84. doi: $10.3168 /$ jds.2014-8914.

Gumber S, Taylor DL, Whittington RJ (2009) Evaluation of the immunogenicity of recombinant stress-associated proteins during Mycobacterium avium subsp. paratuberculosis infection: Implications for pathogenesis and diagnosis. Veterinary Microbiology 137: 290-296. doi: 10.1016/j.vetmic.2009.01.012.

Gurung RB, Purdie AC, Whittington RJ, Begg DJ (2014) Cellular and humoral immune responses in sheep vaccinated with candidate antigens MAP2698c and MAP3567 from Mycobacterium avium subspecies paratuberculosis. Frontiers in Cellular and Infection Microbiology Volume 4, online: http://dx.doi.org/10.3389/fcimb.2014.00093.

Gwozdz JM, Thompson KG, Manktelow BW, Murray A, West DM (2000) Vaccination against paratuberculosis of lambs already infected experimentally with Mycobacterium avium subspecies paratuberculosis. Australia Veterinary Journal 78: 560-6.

Hurley S, Ewing E (1983) Results of a field evaluation of a whole cell bacterin In: Merkal RS (Ed.) Proceedings of the International Colloquium on Paratuberculosis, I; NADC, USDA, International Association for Paratuberculosis Ames, IA, USA Pp. 244-248.

Jorgensen JB (1983) The effect of vaccination on the excretion of Mycobacterium paratuberculosis In: Merkal RS (Ed.) Proceedings of the International Colloquium on Paratuberculosis, I; NADC, USDA, International Association for Paratuberculosis Ames, IA, USA Pp. 249-254.
Juste RA, Perez V (2011) Control of paratuberculosis in sheep and goats. Veterinary Clinics of North America: Food Animal Practice 27: 127-38. doi: 10.1016/j.cvfa.2010.10.020.

Kalis CHJ, Benedictus G, van Weering HJ, Flamand F, Haagsma J (1992) Experiences with the use of an experimental vaccine in the control of paratuberculosis in the Netherlands. $3^{\text {rd }}$ International Colloquium on paratuberculosis Pp. 484-492.

Kalis CH, Hesselink JW, Barkema HW, Collins MT (2001) Use of long-term vaccination with a killed vaccine to prevent fecal shedding of Mycobacterium avium subsp paratuberculosis in dairy herds. American Journal of Veterinary Research 62: 270-274.

Kathaperumal K, Kumanan V, McDonough S, Chen LH, Park SU, Moreira MA, Akey B, Huntley J, Chang CF, Chang YF (2009) Evaluation of immune responses and protective efficacy in a goat model following immunization with a cocktail of recombinant antigens and a polyprotein of Mycobacterium avium subsp. paratuberculosis. Vaccine 27: 123 - 135. doi: 10.1016/j.vaccine.2008.10.019.

Kawaji S, Nagata R, Whittington RJ, Mori Y (2012) Detection of antibody responses against Mycobacterium avium subsp. paratuberculosis stress-associated proteins within 30 weeks after infection in cattle. Veterinary Immunology and Immunopathology 150: 101-11. doi: 10.1016/j.vetimm.2012.09.003.

Klawonn W, Cussler K, Drager KG, Gyra H, Kohler H, Zimmer K (2002) The importance of allergic skin test with Johnin, antibody ELISA, cultural fecal test as well as vaccination for the sanitation of three chronically paratuberculosis-infected dairy herds in Rhineland-Palatinate. Dtsch Tierarztl Wochenschr 109: 510 - 516.

Kormendy B (1994) The effect of vaccination on the prevalence of paratuberculosis in large dairy herds. Veterinary Microbiology 41: 117-125.

Larsen AB, Merkal RS, Moon HW (1974) Evaluation of a paratuberculosis vaccine given to calves before infection. American Journal of Veterinary Research 35: 367-369.

Leroy B, Roupie V, Noël-Georis I, Rosseels V, Walravens K, Govaerts M, Huygen K, Wattiez R (2007) Antigen discovery: a postgenomic approach to paratuberculosis diagnosis. Proteomics 7: 1164-1176.

Liu F, Wu X, Liu W, Li L, Wang Z (2014) Current perspectives on conventional and novel vaccines against peste des petits ruminants. Veterinary Research Communication 38: 307-22. doi: 10.1007/s11259-014-9618-x.

Meeusen ENT, Walker J, Peters A, Pastoret PP, Jungersen G (2007) Current Status of Veterinary Vaccines. Clinical 


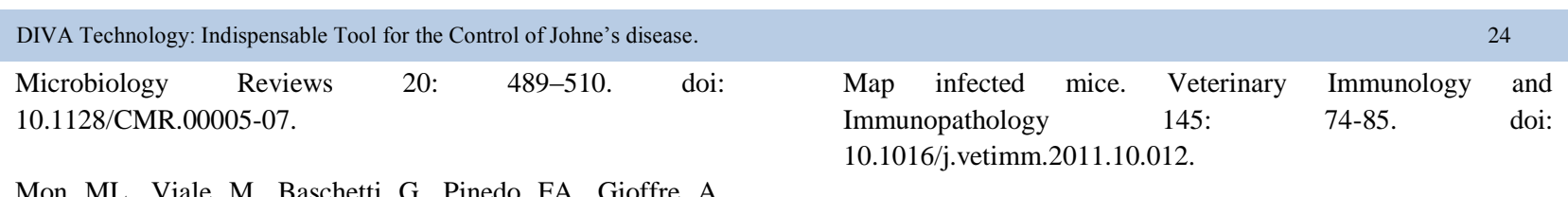
Travería G, Willemsen P, Bakker D, Romano MI (2012) Search for Mycobacterium avium subspecies paratuberculosis Antigens for the Diagnosis of Paratuberculosis. Veterinary Medicine International Article ID 860362, 9 pages. http://dx.doi.org/10.1155/2012/860362.

Olsen I, Tryland M, Wiker HG, Reitan LJ (2001) AhpC, AhpD, and a Secreted 14-Kilodalton Antigen from Mycobacterium avium subsp. paratuberculosis Distinguish between Paratuberculosis and Bovine Tuberculosis in an Enzyme-Linked Immunosorbent Assay. Clinical and Diagnostic Laboratory Immunology 8: 797-801. doi: 10.1128/CDLI.08.4.797-801.2001.

Pasick J (2004) Application of DIVA vaccines and their companion diagnostic tests to foreign animal disease eradication. Animal Health Research Reviews 5: 257-262. DOI: 10.1079/AHR200479.

Rahn J, Hoffmann D, Harder TC, Beer M (2015) Vaccines against influenza A viruses in poultry and swine: Status and future developments. Vaccine 33: 2414-2424. doi: 10.1016/j.vaccine.2015.03.052.

Rawat KD, Chaudhary S, Kumar N, Gupta S, Chaubey KK, Singh SV, Dhama K, Deb R (2014) Economic Losses in a Commercial Dairy Farm due to the Outbreak of Johne's Disease in India. Research Journal for Veterinary Practitioners 2: 73-77. http://dx.doi.org/10.14737/journal.rjvp/2.5.73.77.

Reddacliff L, Eppleston J, Windsor P, Whittington RJ, Jones S (2006) Efficacy of a killed vaccine for the control of paratuberculosis in Australian sheep flocks. Veterinary Microbiology 115: 77 - 90 .

Rosseels V, Marché S, Roupie V, Govaerts M, Godfroid J, Walravens K, Huygen K (2006) Members of the 30- to 32Kilodalton Mycolyl Transferase Family (Ag85) from Culture Filtrate of Mycobacterium avium subsp. paratuberculosis Are Immunodominant Th1-Type Antigens Recognized Early upon Infection in Mice and Cattle. Infection and Immunity 74: 202212. doi: 10.1128/IAI.74.1.202-212.2006.

Roupie V, Leroy B, Rosseels V, Piersoel V, Noël-Georis I, Romano M, Govaerts M, Letesson JJ, Wattiez R, Huygen K (2008) Immunogenicity and protective efficacy of DNA vaccines encoding MAP0586c and MAP4308c of Mycobacterium avium subsp. paratuberculosis secretome. Vaccine 26: 4783-94. doi: 10.1016/j.vaccine.2008.07.009.

Roupie V, Viart S, Leroy B, Romano M, Trinchero N, Govaerts M, Letesson JJ, Wattiez R, Huygen K (2012) Immunogenicity of eight Mycobacterium avium subsp. paratuberculosis specific antigens in DNA vaccinated and
Saxegaard F, Fodstad FH (1985) Control of paratuberculosis (Johne's disease) in goats by vaccination. Veterinary Records 116: 439-441.

Shankar H, Singh SV, Singh PK, Singh AV, Sohal JS, Greenstein RJ (2010) Presence, characterization, and genotype profiles of Mycobacterium avium subspecies paratuberculosis from unpasteurized individual and pooled milk, commercial pasteurized milk, and milk products in India by culture, PCR, and PCR-REA methods. International Journal of Infectious Diseases 14: 121-126. doi: 10.1016/j.ijid.2009.03.031.

Shin SJ, Chang CF, Chang CD, McDonough SP, Thompson B, Yoo HS, Chang YF (2005) In vitro cellular immune responses to recombinant antigens of Mycobacterium avium subsp. paratuberculosis. Infection and Immunity 73: 5074-85.

Sigurdsson S, Gunnarson E (983) Paratuberculosis in sheep, goats and reindeer in Iceland: a result of an import of a flock of sheep from Germany 1933. In: Proceedings of the 1st International Colloquium on Paratuberculosis (ICP '83), Aures, Iowa, USA. pp. 239-244.

Sigurdsson B (1960) A killed vaccine against paratuberculosis (Johne's disease) in sheep. American Journal of Veterinary Research 21: 54-67.

Singh SV, Singh PK, Singh AV, Sohal JS, Gupta VK (2007) Comparative efficacy of an indigenous 'Inactivated vaccine' using highly pathogenic field strain of Mycobacterium avium subspecies paratuberculosis 'Bison type' with a commercial vaccine for the control of Capri - Paratuberculosis in India. Vaccine 25: 7102-7110.

Singh AV, Singh SV, Singh PK, Sohal JS (2010a) Genotype diversity in Indian isolates of Mycobacterium avium subspecies paratuberculosis recovered from domestic and wild ruminants from different agro-climatic regions. Comparative Immunology Microbiology Infectious Diseases 33 :e127-31. doi: 10.1016/j.cimid.2010.08.001.

Singh SV, Singh PK, Singh AV, Sohal JS, Sharma MC (2010b) Therapeutic effects of a new 'Indigenous Vaccine' developed using novel native 'Indian Bison type' genotype of Mycobacterium avium subspecies paratuberculosis for the control of clinical Johne's disease in naturally infected goatherds in India. Veterinary Medicine International Article ID 351846, 8 pages. doi: http://dx.doi.org/10.4061/2010/351846.

Singh SV, Singh AV, Singh PK, Singh B, Rajendran AS, Swainm N (2011a) Recovery of Indian bison type genotype from wild bison (Bos gourus) in India. Veterinary Research 4: 61-65. doi: 10.3923/vr.2011.61.65. 
Singh SV, Singh AV, Singh PK, Kumar A, Singh B (2011b) Molecular identification and characterization of Mycobacterium avium subspecies paratuberculosis in free living non-human primate (Rhesus macaques) from North India. Comparative Immunology Microbiology and Infectious Diseases 34: 267-71. doi: 10.1016/j.cimid.2010.12.004.

Singh SV, Singh AV, Gupta S, Rajindran AS, Swain N, Singh PK, Singh H, Sohal JS, Kumar N (2012) Interspecies Sharing of "Indian Bison Type," A Novel Predominant Genotype of Mycobacterium avium subspecies paratuberculosis between Naturally Infected and Endemic Flocks of Bharat Merino Sheep and a Colony of Rabbits (Oryctolagus Cuniculus) Raised on the Same Ecosystem in South India. Research and Reviews: A Journal of Life Sciences 2: 1-8.

Singh SV, Singh AV, Singh PK, Gupta S, Singh H, Singh B, VinodhKumar OR, Rajendiran AS, Swain N, Sohal JS (2013) Evaluation of 'Indigenous vaccine' developed using 'Indian Bison Type' genotype of Mycobacterium avium subspecies paratuberculosis strain ' $\mathrm{S} 5$ ' of goat origin in a sheep flock endemic for Johne's disease: A three years trial in India. World Journal of Vaccines 3: 52-59. DOI: 10.4236/wjv.2013.32009.

Singh SV, Singh PK, Singh AV, Sohal JS, Kumar N, Chaubey KK, Gupta S, Rawat KD, Kumar A, Bhatia AK, Srivastava AK, Dhama K (2014) 'Bio-Load' and Bio-Type Profiles of Mycobacterium avium subspecies paratuberculosis Infection in the Domestic Livestock Population Endemic for Johne's Disease: A Survey of 28 years (1985-2013) in India. Transboundary and Emerging Diseases 61: 43-55. doi: 10.1111/tbed.12216.

Sohal JS, Singh SV, Singh B, Thakur S, Aseri GK, Jain N, Jayaraman S, Yadav P, Khare N, Gupta S, Chaubey KK, Dhama K (2015) Control of Paratuberculosis: Opinions and Practices. Advances in Animal and Veterinary Sciences 3: 156163. http://dx.doi.org/10.14737/journal.aavs/2015/3.3.156.163.

Souza GS, Rodrigues AB, Gioffré A, Romano MI, Carvalho EC, Ventura TL, Lasunskaia EB (2011) Apa antigen of Mycobacterium avium subsp. paratuberculosis as a target for species-specific immunodetection of the bacteria in infected tissues of cattle with paratuberculosis. Veterinary Immunology
Immunopathology

$143: 75-82$.

doi:

10.1016/j.vetimm.2011.06.026.

Thonney ML, Smith MC (2005) Control of Johne's disease in sheep by vaccination Preliminary Report. Cornell University, USA.

Tiwari A, VanLeeuwen JA, McKenna SLB, Keefe GP, Barkema HW (2006) Johne's disease in Canada: Part I: Clinical symptoms, pathophysiology, diagnosis, and prevalence in dairy herds. Canadian Veterinary Journal 47: 874-882.

van Oirschot JT (1999) Diva vaccines that reduce virus transmission. Journal of Biotechnology 73: 195-205.

van Schaik G, Kalis CH, Benedictus G, Dijkhuizen AA, Huirne RB (1996) Cost benefit analysis of vaccination against paratuberculosis in dairy cattle. Veterinary Records 139: 624627.

Vinodhkumar OR, Gunaseelan L, Ronald BS, Sakthivelan SM (2013) Slaughterhouse prevalence of ovine paratuberculosis in Southern India. Tropical Animal Health and Production 45: 1063-9. doi: 10.1007/s11250-012-0321-z.

Vordermeier HM, Whelan A, Cockle PJ, Farrant L, Palmer N, Hewinson RG (2001) Use of synthetic peptides derived from the antigens ESAT- 6 and CFP-10 for differential diagnosis of bovine tuberculosis in Cattle. Clinical and Diagnostic Laboratory Immunology 8: 571-578.

Wilesmith JW (1982) Johne's disease: a restrospective study of vaccinated herds in Great Britain. British Veterinary Journal 138: $321-331$.

Willemsen PT, Westerveen J, Dinkla A, Bakker D, van Zijderveld FG, Thole JE (2006) Secreted antigens of Mycobacterium avium subspecies paratuberculosis as prominent immune targets. Veterinary Microbiology 114: 33744.

Windsor PA, Eppleston J, Sergeant E (2003) Monitoring the efficacy of Gudair ${ }^{\mathrm{TM}}$ OJD vaccine in Australia. Proceedings of the Australian Sheep Veterinary Society Pp. 114-122. 